\title{
Manifestos, Salience \\ And \\ Junior Ministerial Appointments
}

\section{Abstract}

We build on previous theories of junior minister allocation and coalition oversight by incorporating a novel theory of strategic changes in the issues covered in party manifestos. We argue that parties use junior ministerial appointments to oversee their coalition partners on portfolios that correspond to issues emphasized by the parties' activists when the coalition partner's preferences deviate from the party's. The findings, based on a data set of more than 2800 party portfolio dyads in ten countries, show significant support for these expectations. We find that party leaders that successfully negotiate for junior ministers to particular portfolios are most concerned about checking ideologically contentious coalition partners in areas of concern to activists. The results also illustrate the usefulness of our dyadic approach for the study of junior minister allocation. 


\section{Introduction}

Much research on government formation has focused on the allocation of ministerial portfolios. Increasing attention has been devoted to junior ministerial appointments: especially as a means for coalition partners to constrain each other's actions (Mershon, 2001b; Thies, 2001; Giannetti and Laver, 2005; Lipsmeyer and Pierce, 2011). There has been mixed evidence in support of Thies' (2001) argument that coalition partners use junior ministerial appointments as an oversight mechanism. Giannetti and Laver (2005) found that junior ministers in the Prodi government following the 1996 election in Italy had limited influence over policy outcomes. Lipsmeyer and Pierce (2011) however, found that ideological disagreements between coalition partners largely drive junior ministerial appointments suggesting an important policy dimension.

We build on that work by incorporating a novel theory of strategic changes in the issues covered in party manifestos. We argue that parties will be more likely to use junior ministerial appointments for oversight purposes in portfolios that correspond to issues important to intraparty groups and parties' activists. We add that parties use junior ministers on predominantly activist issues when there is disagreement between the party's preferences and the party holding the ministry. Previous large-N studies of junior minister allocation limit their analysis to the characteristics of the party that controls a minister or to broader characteristics of the coalition. Like Bäck et al. (2011), we use a dyadic, approach that allows us to study the characteristics of each coalition party in relation to each portfolio. This approach allows us to directly account for both the salience of issues parties include in their platforms and the electoral strategies that led parties to include those issues. Our findings, based on a data set of more than 2822 party, portfolio dyad observations from 125 coalitions in ten countries, show significant support for these expectations. 


\section{Junior Ministers and Parties}

The literature on making and breaking governments devotes considerable attention to ministerial portfolios. Much of this literature focusses on the distribution of cabinet posts among coalition partners (e.g. Warwick and Drukman, 2001; Proksch and Slapin, 2006; Carroll and Cox, 2007; Bäck et al., 2011) or among factions within parties (Mershon, 2001a, 2001b). The presumed motive for winning a portfolio is the value of holding the ministerial position per se. While policy salience is often an important factor in these analyses, the use of junior ministerial appointments as a means of monitoring coalition partners is not a primary focus.

Additional research focuses on the durability and termination of coalitions (Strøm et al., 1994; Laver and Shepsle, 1996; Martin and Vanberg, 2003; Timmermans, 2006). This literature raised important questions about the nature of delegation within parliamentary systems. This research instead focused on accountability within parliamentary governments and the means by which coalition parties oversee each other's actions within the ministries (Strøm, 2000; Thies, 2001; Martin and Vanberg, 2004, 2005; Giannetti and Laver, 2005; Kim and Loewenberg, 2005). One of the most prominent oversight mechanisms discussed in this literature is the use of junior ministerial appointments by coalition parties to "keep tabs" or act as "watchdogs" over their partners (Thies, 2001; Falcó-Gimeno, 2012).

In the original "keeping tabs" argument, Thies argues that when Party A wants to know how a minister from Party B is managing a particular ministry, Party A will appoint one of their own as a junior minister to act as a watchdog. This logic is similar to fire alarm oversight. In the "keeping tabs" scenario and the fire alarm oversight story, the goal is to provide information about the agent's behavior. In keeping with this logic, a watchdog with dissimilar preferences to 
the agent being watched will have the greatest incentive to report any attempt by the minister to deviate from the agreed upon policy. Consistent with this perspective, Lipsmeyer and Pierce (2011) found that junior ministers tend to be ideologically dissimilar from their corresponding ministers.

Although they enjoy less publicity and attention than ministers do, junior ministers have the potential to affect coalition governance. Much of the research on junior ministers presumes that parties primarily use them for policy seeking motives and that they have an impact on policy (Thies, 2001; Mershon, 2001a, 2001b; Giannetti and Laver, 2005; Lipsmeyer and Pierce, 2011). However, most research predicts junior minister allocation without fully considering the policy goals of the coalition members. We contend that understanding junior ministerial appointments requires first exploring parties' policy goals.

Studies of electoral strategy have long focused on ideology as a tool to attract voters (Downs, 1957). Parties also use the issues in their platforms to strategically emphasize some topics (Petrocik, 1996) or to engage in issue entrepreneurship to attract new voters (Meguid, 2007; Ezrow, 2008; Ezrow et al., 2011; Spoon, 2011; De Vries and Hobolt, 2012) even if the electoral gains lag policy change by some time (Adams and Somer-Topcu, 2009). Indeed, governing parties sometimes adopt extreme positions to attract voters (Bawn and Somer-Topcu, 2012). ${ }^{1}$ Parties are freer to change positions on some issues more than others (Tavits, 2007) and avoid discussing issues on which their supporters are divided (Wardt, 2012). Governing parties are more likely to change the issues in their campaigns than opposition parties (Schumacher, de Vries and Vis, 2013). We expect that parties add issues to their platform to expand the scope of conflict and mobilize otherwise uninterested voters. The logic is based on Schattschneider's (1960) perspective in which political actors expand the scope of conflict by bringing up new 
issues to mobilize supporters. However, intra-party groups and policy reputations offer incentives for parties to focus on a smaller number of important issues because party leaders rely on the support of party factions (Harmel and Janda, 1994; Harmel and Tan, 2003; Ceron, 2012). Likewise, parties face difficulties changing their reputation with voters from one set of issues to another because of long standing constituencies and governing history. Electoral constraints and policy reputations therefore influence the range of issues on which parties can credibly campaign (Tavits, 2007; Green, 2011; Green and Jennings, 2011).

Building on this perspective, we expect that parties increase the number of issues in their platforms to attract voters, but reduce the number of issues in their platforms to mobilize party activists and emphasize their traditional competencies. Parties choose between each strategy as they pursue a focused or broad electoral appeal (Green, 2011). Both strategies seek to maximize vote shares, but follow alternate logics dependent on electoral context. Parties focus on their 'owned' issues or those for which they are historically known to rebuild a reputation for competence (Green, 2011). By decreasing the number of issues, parties focus their platform on the issues for which they have and seek to emphasize a reputation of competence as well as outline more detailed policy goals on those issues (Green and Jennings, 2011). However, parties' limit the detail or specificity of their policy statements as they add new, less traditionally important issues (Rovny, 2011; De Vries and Hobolt, 2012). Parties perceived as more popular are freer to campaign on a wider range of issues (Green, 2011). Therefore, when party leaders add issues to their platforms they broaden the scope of the platform to attract voters. Conversely, when leaders reduce the number of issues, they narrow the platform's focus to their traditional issues linked to their historical constituencies (Green, 2011). This leads us to describe issues added to attract electoral support as voter issues. We label issues on which parties have a long 
term reputation and that the party focuses on to mobilize their historical constituencies as activist issues. ${ }^{2}$ Activist issues are those issues that parties have emphasized for long periods of time, that they retain in their platforms even when they narrow their scope, and which motivate activists within the party upon which the party depends for smooth functioning. Voter issues are those which parties recently added, that the party is less specific about and which the most established and long standing party activists have little concern.

Party leaders decrease the number of issues in the platform in response to electoral losses and policy failures. These losses create the perception within the party that their previous pragmatic strategies have failed. However, party leaders discuss a broader range of issues when the party has had previous electoral successes or controls government. For example, the French Parti Socialiste (PS) increased the number of issues they campaigned on to attract voters prior to their 1993 election because of their previous electoral success and experience in office. In 1997, the PS decreased the number of issues to mobilize the party's base and emphasize their competencies after their electoral losses in the previous election. Therefore, issues that the PS added to their platforms or increased in emphasis in 1993 were intended to pragmatically attract voter groups, whereas the issues that the PS increased in emphasis in 1997 were core issues linked to intra-party groups. In addition, those issues that the party decreases in emphasis as it changes the total number of issues in the platform provide information about the party's principals. In 1993, the PS watered down its policy focus or decreased the percentage of the platform dedicated to issues important to intra-party groups as it added new issues to attract voters. However, as the party narrowed its platform to a smaller number of intra-party policy goals in 1997, they removed or de-emphasized issues that had been included to attract voters in the previous election. 
We expect that parties' engage in more policy seeking behaviors in government on activist issues because of their long term importance to the parties' historical policy reputations, constituencies and activists. ${ }^{3}$ Like studies of party policy change (Tavits, 2007), we predict that parties act consistently on issues important to these groups for fear of appearing unprincipled. Coalition formation is one of the most important arenas for policy seeking behavior in parliamentary democracies. Because policies are largely formed and implemented in the ministries, the ministers assigned to the various coalition parties have substantial policy implications. One might argue that ministerial positions are high profile symbols and that policy matters are only part of their role. However, junior ministers are not as much in the public eye as ministers. For example, newspaper accounts of new coalition governments report the names and party affiliations of the ministers but rarely report such detail about the junior ministers. Furthermore, following recent research on "watchdog junior ministers," we argue that these are policy management positions (Mershon, 2001b; Thies, 2001; Lipsmeyer and Pierce, 2011; FalcóGimeno, 2012). They do not have the symbolic status of being responsible for some policy portfolio, but they do have significant policy roles. In distinguishing between policy and vote seeking motives, we contend that junior ministerial appointments lean heavily in the policy seeking direction.

Furthermore, Fortunato and Stevenson (2013) contend that voters in parliamentary systems pay more attention to easily observable events, such as whether or not a party is in a particular coalition at all. Since junior ministerial appointments are relatively low visibility events, we expect that activists will pay greater attention to them than more typical voters. As a consequence, party leaders' priorities should be more constrained by the preferences of activists than voters. For these reasons, we contend that parties use junior ministers primarily on activist 
issues because these issues are important to the party's activists, policy reputation and historically interested constituents. Furthermore, we assume that the number of junior ministerial appointments a party can make is limited. If parties could appoint junior ministers to every ministry without restriction, they might be expected to do so. So long as parties must negotiate which ministry to assign a junior minister, they prioritize assignments to the portfolios most important to the long standing policy goals of party activists. This leads us to our first hypothesis.

H1: Parties will be more likely to allocate junior ministers on issues the party used to motivate party activists (activist issues).

If policy goals drive junior minister allocation and appointments are limited, parties might also focus their appointments on those portfolios where the minister has policy preferences that deviate from their own. This is in keeping with research showing a relationship between junior minister allocation and the ideological distance between the minister and junior minister (Lipsmeyer and Pierce, 2011; Martin and Vanberg, 2011). Furthermore, coalitions are less likely to utilize oversight mechanisms on issues when only one coalition party holds that issue salient (Falcó-Gimeno, 2012). The underlying logic of Thies' (2001) original argument is that watchdog junior ministers are enforcing coalition agreements. If junior ministerial appointments enforce the coalition agreement, the incentive for a party to bargain for a particular appointment would depend in part on the ideological disagreement between the minister and the party's policy position. That is, when ideological differences are small, there is more trust between the appointing party and the party that holds the ministry. But, greater ideological distance increases 
the incentive to monitor the ministry. We have argued that parties are more likely to prioritize a junior minister to a portfolio that coincides with activist issues. If parties allocate junior ministerial appointments based on ideological differences with their coalition partners, we should see an interaction between the ideological distance between ministers and the coalition's preferences on the one hand and whether the portfolio relates to an activist issue. This leads us to our second and final hypothesis.

H2: Parties will be more likely to allocate junior ministers on activist issues when the party controlling the portfolio is ideologically distant from the party with the potential to appoint a junior minister (activist issues Xideological disagreement).

\section{Data and Methods}

Our unit of analysis is the party-portfolio dyad for each coalition government. Previous research has used a number of different units of analysis. For example, Thies (2001) primarily analyzed the aggregate applications of junior ministers across countries. Lipsmeyer and Pierce (2011) predicted the likelihood that a portfolio in a coalition included at least one junior minister. However, neither approach easily lends itself to the analysis of individual party characteristics and their effect on portfolio allocation. We use a dyadic approach because it allows us to test predictions on the effect of individual parties' characteristics on their allocation of junior ministers. ${ }^{4}$

In our analysis, every possible portfolio that each party in each government could allocate a minister or junior minister to is an observation. For example, the Prodi government following the 1996 election in Italy included four parties. For each ministry we made four observations; 
one observation for each party in the cabinet that could have assigned a junior minister. We pool data on all coalition governments from Austria (1949-1998), Belgium (1961-1998), Germany (1953-1998), France (1959-1997), Ireland (1948-1998), Italy (1946-1998), the Netherlands (1946-1998), Norway (1961-1998), Portugal (1978-1985), and Sweden (1951-1994). This generates a total of 9019 party-portfolio dyads for which Strøm and Müller (2000) have data about junior ministerial appointments. ${ }^{5}$

Our dependent variable is a dummy variable that equals one if the party in the partyportfolio dyad contributes a junior minister to that portfolio and a zero if not using data from Strøm and Müller (2000). In some cases, where a party allocated multiple junior ministers to the same portfolio we entered a value of one. In cases where multiple parties allocated junior ministers to the same portfolio, we entered a value of one for each party-portfolio dyad. While previous monadic analyses would have only observed that a junior minister had been allocated to a portfolio in this scenario, our dyadic approach allows us to analyze each party's decision to allocate a junior minister. We coded each party-portfolio dyad as zero where a junior minister or minister was a non-party appointee.

Because the theory links specific issues important to parties' election campaigns to their preferences for policy on a portfolio, we combine the junior ministers data with the Comparative Manifestos Project (CMP) (Budge et al., 2001; Klingemann et al., 2006). The CMP measures the percentage of statements parties include in their electoral platforms on 56 issues. Using the CMP, we operationalize the primary independent variables as a set of variables to indicate the principals (voters or party activists) motivating the party to discuss those issues and the amount of attention those issues receive in the party's platform. We code the measures for voter and party activist issues based on recent theories of party competition. 
Following the logic of Greene (2012), parties add new issues to their platforms to attract and mobilize voters or they decrease the number of issues in their platforms to focus their attention on a smaller number of issues to mobilize their activists and emphasize their historical competencies (Green 2011; De Vries and Hobolt, 2012). While parties follow both strategies, the conditions in which an issue is emphasized or deemphasized indicates the specific principal (voter groups or party activists) that motivates parties' statements on those issues

Developing a coding scheme based on this logic, we identify which issues discussed in the platform are supported by voters or activist groups. In particular, when a party increases the percentage of the platform devoted to an issue while increasing the total number of issues covered, we classify that issue as a voter issue. ${ }^{6}$ We also code voter issues as those issues that the party removes or decreases the percentage of statements on when the party decreases the number of issues in its platform because the party decreases the number of issues to focus its attention on the policy goals of its activists. For example, if a party deemphasizes an issue while it is also narrowing the focus of the platform to fewer issues, the deemphasized issue is said to be a voter issue. Parties remove or deemphasize issues that are less central to their policy goals when the number of issues in their policy platforms decrease. For each voter issue we measure the percentage of policy statements in the platform dedicated to that topic.

We operationalize party activist issues as those issues that the party increases the percentage of statements on when it reduces the number of issues. An activist issue is one that enjoys increased emphasis in the platform when the party reduces the number of issues. We also code activist issues as those issues that the party decreases attention to when the party increases the number of issues because the party adds new issues to the platform to attract voters. This waters down or dilutes the attention to these issues when the party increases the number of 
issues. Issues that were present in the platform before the party added new issues to it are activist issues despite their decreased emphasis. This decrease in emphasis is an artifact of the platform being expanded to include new issues. These indicators of voter and activist issues reflect topics the party includes in its electoral platform and the principals that motivated statements on those topics.

For example, the Belgian Francophone Socialists (FS) in 1991 increased the percentage of its platform on issues of political decentralization (CMP code 301 ) from $5.68 \%$ to $7.15 \%$. In their 1991 platform, the FS increased the overall number of issues in their platform. We code political decentralization as a voter issue in this year. Similarly, we code political decentralization for the FS as a voter issue in the 1995 election because they decrease the percentage of statements on decentralization to $1.69 \%$ as the party reduces the total number of issues in the platform that year.

In contrast to political decentralization, the FS decreased the percentage of statements on education expansion (CMP code 506) in their platform from $8.17 \%$ to $5.86 \%$ between 1987 and 1991 along with the broader increase in the number of issues in the party's platform. The percentage of statements slightly increased to $6.08 \%$ in the 1995 election when the party reduced the total number of issues in the platform. We code educational expansion as an activist issue for both the 1991 and 1995 elections.

We link these issue indicators to ministries by coding the percentage of the platform on these issues that fall under the portfolio's jurisdiction. We limit our analysis to the 13 categories of portfolios analyzed by Bäck et al. (2011). ${ }^{7}$ Following their logic, we attach the same CMP categories to the portfolios in all countries. This coding scheme results in 2822 party, portfolio dyadic observations in 125 coalition governments with sufficient information on parties' issue 
priorities in countries that make use of junior ministers. ${ }^{8} 28 \%(791)$ of party, portfolio dyad observations have a junior minister associated with it. Summary statistics for the variables are presented in Table $1 .{ }^{9}$

\section{$* * *$ INSERT TABLE 1 HERE***}

To test the hypotheses, we include interactions of these issue variables with ideological disagreement. We construct parties' ideological left-right position using Lowe et al.'s (2011) logged measure of ideology. We then find the level of disagreement by taking the absolute difference between left-right position of the party that controls the portfolio and the party choosing to allocate a junior minister. The interactions of disagreement and issue type represent the difference between the ideology of the portfolio party with each of its coalition partners on each party’s voter and activist issues.

We include a number of controls from the traditional literature. Like Lipsmeyer and Pierce (2011), we measure disagreement between the coalition mean position and the party of the minister's ideological position and interact this disagreement with Warwick and Druckman's (2005) measure of portfolio importance. We expect that portfolio ranking increases the likelihood of junior ministers when there is greater disagreement. Following Bäck et al. (2011), we include a dummy variable to indicate parties' preferences for portfolios based on their historical party family. For example, socialist parties may be more likely to allocate junior ministers linked to the Labor, Social Affairs, or Health ministries. ${ }^{10}$ We also include a control variable for whether a party holds the minister on a portfolio. We use the conditional logit model to account for additional confounding factors, although it limits our ability to include institutional or other variables that do not vary across government parties. ${ }^{11}$ 
We use a conditional logit model to test the hypotheses. Both the use of the conditional logit and our construction of the unit of analysis in a dyadic framework mark a methodological improvement on previous studies of junior minister allocation. Using a dyadic approach, we directly test hypotheses that make predictions between the ideological characteristics of each coalition party with characteristics of the party that controls the portfolio. However, this also introduces a number of issues for the analysis because observations are not entirely independent of each other. To account for this lack of independence, scholars of coalition formation and portfolio allocation have increasingly turned to the conditional logit model (Bäck and Dumont, 2008; Bäck et al., 2011). ${ }^{12}$ The approach here follows the logic that the government party is the unit of analysis and the government portfolios are the discrete choice alternatives. ${ }^{13} 14$

\section{Analysis}

We present the results of our analysis in Table 2. In Model 1, we begin with a base model. Model 1 provides limited support for our first hypothesis that parties will be more likely to assign junior ministers to portfolios that correspond to activist issues. The activist issue variable has the expected sign, but is not quite statistically significant at conventional levels. This result is consistent with Bäck et al.'s (2011) finding that issue salience influences portfolio allocations. This initial finding weakly supports Hypothesis 1. However, past research showing a major role for ideological disagreement suggests a more complex relationship.

We proceed with a test of Hypothesis 2 in Model 2. Model 2 includes an interaction between the measures of issue type and ideological disagreement between each party's and the minister's party's preferences. This specification allows us to test which issues parties engage in 
oversight activities on their ideologically distant coalition partners. The results in Model 2 confirm Hypothesis 2.

\section{$* * *$ INSERT TABLE 2 HERE***}

Including the interaction between our issue type variables (activist and voter issues) and ideological disagreement between the minister and the party tells a slightly fuller story than Model 1's ideologically naïve approach. The results offer support for our second hypothesis. Model 2 shows that parties are more likely to allocate junior ministers on activist issues when faced with ideological disagreement. In particular, the coefficient for the interaction of activist issues and disagreement is positive and significant. Furthermore, a Wald test of the joint significance of the coefficients for activist issues and its interaction with ideological disagreement is positive and significant with $95 \%$ confidence based on Model 2 . This finding is consistent with the evidence presented in Lipsmeyer and Pierce (2011) that disagreement is an important predictor of junior ministerial allocation. Namely, there is an interaction between the type of issue corresponding to the portfolio and the nature of the relationship between ideological disagreements and junior minister allocation. Importantly, the substantive impact of the coefficient for the interaction is positive. The effect of ideological disagreement between the portfolio party and each coalition party indicates that parties are more likely to use junior ministers on activist issues than other issues when they disagree with the party controlling the portfolio.

While the evidence in Model 2 supports the logic of $\mathrm{H} 2$, the coefficients alone leave unclear an unclear picture of the substantive magnitude of the effect of each type of issues. Therefore, in Figure 1, we predict the change in the likelihood of a junior minister on activist issues for high levels of ideological disagreement with $90 \%$ confidence intervals. ${ }^{15} 16$ 
For higher values of disagreement, activist issues have a stronger positive impact on the odds of a junior minister, as Figure 1 illustrates. A party with 10\% of its platform on an activist issue and high ideological disagreement with the party controlling that portfolio has a .084 higher likelihood of having a junior minister on that portfolio than a party with zero percent of its platform on that issue. Although the effect of increasing issue salience is quite large, the change is only weakly significant for the full range of issue salience. The variable's clearest effect is relative to those issues which are not salient. In other words, appointments are driven by ideological differences most consistently when party activists care about the issue. For example, the theory predicts the behavior of the Italian Democratic Socialist Party in 1979; faced with a number of ideologically distant coalition partners that controlled 13 total cabinet positions, the PSDI placed junior ministers on six portfolios; four of these cabinets were linked to activist issues: Defense, Finance, Interior and Labor. The issues attached to each of these portfolios occupied a large percentage of the PSDI's platform in 1979.

This emphasis on activist issues provides strong circumstantial evidence in support of Thies's (2001) keeping tabs argument. To the extent that activist issues represent policy seeking motives, we should expect more watchdog junior minister appointments in the corresponding portfolios. That we find that ideological disagreement has a stronger effect on junior minister allocation in issue areas that party activists care most about, suggests that the oversight capacity of junior ministers figures prominently in their appointment to particular portfolios. If oversight were not playing a role, we might expect there to be no difference between salient activist issues and issues parties do not include in their platforms.

Furthermore, most of the control variables are in the predicted directions. For issues parties do not include in their platform, increased disagreement between coalition members for 
unimportant ministries decreases the likelihood of a junior minister and voter issues increase the probability, although the coefficients are not statistically different from zero. As predicted by Lipsmeyer and Pierce (2011), the interaction of disagreement and portfolio rank is positive, but not statistically significant. In contrast to Bäck, et al. (2011), we find that expectations based on the party's family are negative and statistically different from zero. This may suggest that parties are more interested in controlling the cabinet minister (or do control the cabinet minister) than overseeing their coalition partners on these issues.

If a major component of the portfolio importance measure is picking up the effect of parties' long term issue based preferences for specific ministries, then our dynamic and party based measures of preferences may be an alternative measure of that component of portfolio importance. The effect of portfolio importance left over in the model is the underlying ranking of portfolio importance as it relates to office seeking goals, but that has less to do with policy disagreements between coalition members. Interestingly, by directly including the differences between the party controlling the portfolio and both the coalition's mean position and each party's ideological disagreement, we find clearer evidence that each party's policy goals drive most junior minister placements, rather than broader goals to protect the coalition's negotiated position.

\section{Conclusions}

Our study builds on research on intra coalition politics by providing additional evidence that parties use junior ministers as a tool to constrain or limit their coalition partners (Mershon, 2001; Thies, 2001; Lipsmeyer and Pierce, 2011; Martin and Vanberg, 2011; Falcó-Gimeno, 2012). Our findings move the analysis of watchdog junior ministers towards a conceptualization 
that does not demand treating parties as unitary actors. While we still rely on party positions for our ideological distance calculations, we distinguish between issue areas that appeal to different aspects of the party's strategies: its activists and its voters. We add the policy demands of activists within the parties to existing understanding of junior ministerial appointments. Our findings are consistent with studies finding that parties use junior ministers on portfolios controlled by ideologically distant coalition partners (Lipsmeyer and Pierce, 2011; Martin and Vanberg, 2011). However, we specify the types of issues that lead ideologically contentious coalition partners to monitor cabinet ministers. We find that parties devote their resources to monitoring ideologically distant cabinet ministers on issues important to the party's activists. This is especially interesting in light of Bawn and Somer-Topcu's (2011) finding that governing parties adopt extreme positions to attract voters. Our findings suggest that a party may not be particularly bothered by their coalition partners' extreme positions on issues unimportant to the party's activists. This result complements Falcó-Gimeno's (2012) finding that coalitions are less likely to use control mechanisms on issues which are tangential or only salient to one coalition partner.

Our findings provide additional clarification for the watchdog junior minister thesis (Thies, 2001). They join a growing number of works that show a relationship between policy preferences and junior ministerial appointments. If junior ministers truly have no influence on policy outcomes, it is strange to see that policy preferences, especially of party activists, have significant impact on their appointment. However, junior ministers may serve multiple functions and this may lead to additional explanations for why parties negotiate for junior ministers on some portfolios and not others. 
Furthermore, our results suggest that party leaders behave as if voters are less consistently interested in policy outcomes than are activists. The party leaders are much more concerned about checking ideologically contentious coalition partners in areas of concern to activists than they are for areas of concern to voters. Given that party leaders are often constrained and selected through intra-party processes, party leaders' preferences likely closely match those of intra-party groups (Ceron, 2012). This suggests that junior ministerial appointments are motivated more by their historical and long term policy goals as opposed to shorter term appeals to voters. It also implies that parties' leaders do not expect to be held accountable by voters for policy outcomes linked to these appeals. In contrast, parties' leaders seem to expect to be held accountable by their own activists and historical policy competencies.

The results of the analysis also suggest that by distinguishing between the goals of parties' supporters, researchers can better understand the politics of coalition governments and their policy outcomes. Future studies of junior minister allocation and coalition behavior may benefit from examining the diverse reasons why parties include issues in their platforms. A deeper understanding of the party decision-making process will likely point to different ways parties seek to maintain their image of accountability with diverse political groups. 


\section{Appendix}

Like Greene (2012) we construct the primary independent variable, by considering the role of issues in intra-party politics. We first generate a measure of the number of issues in the party's platform by measuring the effective number of manifesto issues (ENMI) based on Laakso and Taagepera's (1979) function for measuring the number and distribution of votes or seats parties receive in an election. Following Lowe et al. (2011), we combine the pairs of confrontational issues so that they represent the percentage of the platform on the issue. ${ }^{17}$

ENMI measures the number and relative distribution of issues parties include in their platforms. The equation below illustrates how we construct the ENMI from the CMP. The letter $m$ refers to the percentage of the manifesto on an issue and subscript, $i$, indicates the specific issue. For example, when a party includes two statements separate statements in the platform, the $\mathrm{ENMI}=2$.

$$
\begin{gathered}
E N M I=\frac{1}{\sum\left(m_{i}^{2}\right)} \\
E N M I=\frac{1}{\sum\left(.5_{1}^{2}+.5_{2}^{2}+0_{3}^{2}+\cdots+0_{49}^{2}\right)} \\
E N M I=2
\end{gathered}
$$

We expect that parties increase their ENMI to follow pragmatic strategies to attract voters or decrease the number of issues in their platforms to appease party activists. Actors increase the scope of conflict to mobilize potential supporters, but are motivated to refocus their message on their core issues (see for example Green, 2011). Therefore, the issues parties add to their platforms when they increase the number of issues and remove when they decrease the number of issues are intended to mobilize voters. We code issues that decrease in percentage as the 
ENMI increases, but increase in percentage as the ENMI decreases are activist. The following statements summarize the operationalization of the primary independent variables where subscript, $i$ refers to individual issues in the party's platform, $t$ refers to the most recent election, and $m$ is equal to the percentage of the manifesto discussing an issue.

$$
\begin{aligned}
& \text { Voter Issue }_{\boldsymbol{i}}=m_{i} \text { if } E N M I_{t-1}-E N M I_{t}>0 \text { and } m_{i, t-1}-m_{i, t}>0 \\
& \text { or } \\
& E N M I_{t-1}-E N M I_{t}<0 \text { and } m_{i, t-1}-m_{i, t}<0 \\
& \text { Activist Issue }_{\boldsymbol{i}}=m_{i} \text { if ENMI } I_{t-1}-E N M I_{t}<0 \text { and } m_{i, t-1}-m_{i, t}>0 \\
& \text { or } \\
& E N M I_{t-1}-E N M I_{t}>0 \text { and } m_{i, t-1}-m_{i, t}<0
\end{aligned}
$$


Table 1. Descriptive Statistics

\begin{tabular}{cccccc}
\hline & Mean & $\begin{array}{c}\text { Standard } \\
\text { Deviation }\end{array}$ & Min & Max & $\mathrm{N}$ \\
\hline Junior Minister & .175 & .38 & 0 & 1 & 5013 \\
\hline$\%$ Activist Issue & 1.093 & 2.1 & 0 & 77.778 & 4321 \\
\hline$\%$ Voter Issue & 1.108 & 1.879 & 0 & 57.786 & 4874 \\
\hline $\begin{array}{c}\text { Party-Minister } \\
\text { distance }\end{array}$ & .246 & .298 & 0 & 1.734 & 4874 \\
\hline $\begin{array}{c}\text { Portfolio } \\
\text { Importance }\end{array}$ & 1.142 & .283 & .5 & 1.92 & 5007 \\
\hline $\begin{array}{c}\text { Coalition-Minister } \\
\text { distance }\end{array}$ & .194 & .169 & 0 & .824 & 4968 \\
\hline Party family & .182 & .386 & 0 & 1 & 5013 \\
\hline
\end{tabular}


Table 2. Conditional Logit Analysis of Junior Minister Allocation

\begin{tabular}{|c|c|c|}
\hline & $\begin{array}{c}(1) \\
\text { Simple }\end{array}$ & $\begin{array}{c}(2) \\
\text { Full } \\
\end{array}$ \\
\hline$\%$ Activist Issue & $\begin{array}{c}0.021 \\
(0.255)\end{array}$ & $\begin{array}{l}-0.010 \\
(0.744)\end{array}$ \\
\hline $\begin{array}{c}\text { Party-Minister Distance X } \\
\text { Activist Issue }\end{array}$ & & $\begin{array}{l}0.162^{+} \\
(0.051)\end{array}$ \\
\hline$\%$ Voter Issue & $\begin{array}{c}0.057 \\
(0.122)\end{array}$ & $\begin{array}{c}0.020 \\
(0.693)\end{array}$ \\
\hline $\begin{array}{c}\text { Party-Minister Distance X } \\
\text { Voter Issue }\end{array}$ & & $\begin{array}{c}0.191 \\
(0.166)\end{array}$ \\
\hline Party-Minister distance & $\begin{array}{l}-0.171 \\
(0.610)\end{array}$ & $\begin{array}{l}-0.529 \\
(0.170)\end{array}$ \\
\hline Portfolio Rank & $\begin{array}{l}0.732^{* *} \\
(0.005)\end{array}$ & $\begin{array}{l}0.714^{* *} \\
(0.006)\end{array}$ \\
\hline Coalition-Minister Distance & $\begin{array}{l}-0.374 \\
(0.799)\end{array}$ & $\begin{array}{l}-0.523 \\
(0.724)\end{array}$ \\
\hline $\begin{array}{c}\text { Coalition-Minister Distance } \\
\text { X Portfolio Rank }\end{array}$ & $\begin{array}{c}0.487 \\
(0.648)\end{array}$ & $\begin{array}{c}0.598 \\
(0.577)\end{array}$ \\
\hline Party family & $\begin{array}{l}-0.271^{+} \\
(0.066)\end{array}$ & $\begin{array}{l}-0.273^{+} \\
(0.062)\end{array}$ \\
\hline Minister's Party & $\begin{array}{l}-1.834^{* * *} \\
(0.000)\end{array}$ & $\begin{array}{l}-1.829^{* * *} \\
(0.000)\end{array}$ \\
\hline Pseudo $R^{2}$ & 0.116 & 0.118 \\
\hline Log likelihood & -926.685 & -924.746 \\
\hline Observations & 2822 & 2822 \\
\hline
\end{tabular}

Note: Results are from conditional logit analyses predicting the application of a junior minister on a portfolio. 1561 party-portfolio observations are dropped because the dependent variable is zero for all outcomes. The models are estimated using a party-government id. $p$-values in parentheses: ${ }^{+} p<0.10,{ }^{*} p<0.05,{ }^{* *} p<0.01,{ }^{* * *} p<0.001$. 
FIGURE 1: Predicted Effect of Activist Issues and Ideological Disagreement

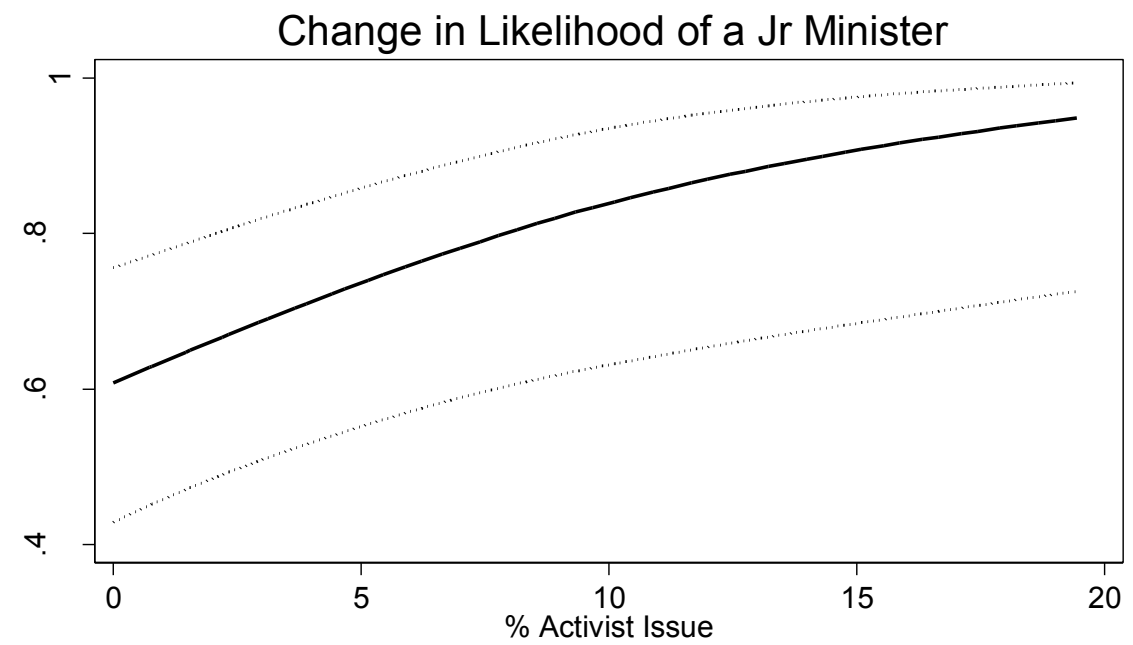

NOTE: The graph plots the change in the likelihood of a party placing a jr minister on a portfolio as the percent of the party's manifesto dedicated to the issue increases at two standard deviations above the mean level of ideological disagreement. $90 \%$ confidence intervals are simulated from 1000 draws of the variance covariance matrix. Predictions are from the Logit estimates in Model 2. Continuous control variables are held at their means and dichotomous variables are held at zero. Predictions are smoothed using Lowess. 


\section{Funding Acknowledgement}

This work was supported by the Collaborative Research Center (SFB) 884 "Political Economy of Reforms" (Project C2), funded by the German Research Foundation (DFG). 


\section{Author Biographies}

Zachary Greene is a Post-Doctoral Researcher at the Collaborative Research Center (SFB 884) the "Political Economy of Reforms" at the University of Mannheim. His research focuses on the role of intra-party politics in parties' electoral campaigns and behavior in government. He currently coordinates a multi-national project to collect documents and speeches from intra-party meetings with the goal of better understanding how intraparty politics influences parties' decision-making process. His dissertation and ongoing research also looks at the broad influences on the diversity of issues in their election campaigns and the consequence of issue competition for government policies.

Christian B. Jensen is an Assistant Professor of Political Science at the University of Nevada, Las Vegas. His research interests include delegation and oversight and the relationship between legislative institutions and parties. Examples of his recent research include: "Procedural Change and the Sources of Ex Ante Constraints in EU Legislation" (2011) Governance 24(3), (with Jae-Jae Spoon) “Compelled Without Direction: Compulsory Voting and Party System Spreading" (2012) Electoral Studies30(4), and (with Oli Proksch and Jon Slapin) "Parliamentary Questions, Oversight and National Opposition Status in the European Parliament" (2013) Legislative Studies Quarterly 38(2). 


\section{Bibliography}

Adams, James, Lawrence Ezrow and Zeynep Somer-Topcu. (2011). "Is Anybody Listening? Evidence that Voters Do Not Respond to European Parties' Policy Statements During Elections." American Journal of Political Science, 55(2): 370-382.

Bäck, Hanna, Marc Debus, and Patrick Dumont. (2011). "Who Gets What In Coalition Governments? Predictors of Portfolio Allocation in Parliamentary Democracies" European Journal of Political Research. 50: 441-478.

Bäck, Hanna, and Patrick Dumont. (2008). "Making the First Move: A Two-stage Analysis of the Role of Formateurs in Parliamentary Government." Public Choice 135: 353-373.

Bawn, Kathleen and Zeynep Somer-Topcu. (2012). "Government Versus Opposition at the Polls: How Governing Status Affects the Impact of Policy Positions." American Journal of Political Science 56(2): 433-446.

Budge, Ian, Hans-Deiter Klingemann, Andrea Volkens, and Judith Bara. (2001). Mapping Policy Preferences. Estimates for Parties, Electors and Governments 1945-1998. Oxford: Oxford University Press.

Carroll, Royce and Gary Cox. (2007). "The Logic of Gamson's Law: Pre-election Coalitions and Portfolio Allocations.” American Journal of Political Science 51 (2): 300-313.

Ceron, Andrea. 2012. Bounded Oligarchy: How and When Factions Constrain Leaders in Party Position-Taking. Electoral Studies 31 (4): 689-701.

De Vries, Katherine and Sarah Hobolt. 2012. "When Dimensions Collide: The Electoral Success of Issue Entrepreneurs." European Union Politics (13): 246-268.

Downs, Anthony. (1957). An Economic Theory of Democracy. New York: Harper.

Druckman, James N., and Paul V. Warwick. (2005). "The Missing Piece: Measuring Portfolio Salience in Western European Parliamentary Democracies.' European Journal of Political Research 44 (1): 17-42.

Ezrow, Lawrence. 2008. "On the Inverse Relationship between Votes and Proximity for Niche Parties." European Journal of Political Research 47: 206-220.

Ezrow, Lawrence, Catherine De Vries, Marco Steenbergen and Erica Edwards. 2011. "Mean Voter Representation and Partisan Constituency Representation: Do Parties Respond to the Mean Voter Positions or to Supporters" Party Politics 17(3): 275-301. 
Falcó-Gimeno, Albert. 2012. "The Use of Control Mechanisms in Coalition Governments: THe Role of Preference Tangentiality and Repeated Interactions." Party Politics : 1-24.

Falcó-Gimeno, Albert, and Indridi H. Indridason. 2013. "Uncertainty, Complexity, and Gamson's Law: Comparing Coalition Formation in Western Europe.” West European Politics 36(1): 221-47.

Fortunato, David and Randolph Stevenson. 2013. "Perceptions of Partisan Ideologies: The Effect of Coalition Participation”American Journal of Political Science 57(2): 459-477.

Giannetti, Daniela, and Michael Laver. (2005). "Policy Positions and Jobs in the Government.' European Journal of Political Science 44 (1): 91-120.

Green, Jane. 2011. "A Test of Core Vote Theories: The British Conservatives, 1997-2005." British Journal of Political Science 41(4): 735-64.

Green, Jane and Will Jennings. (2011). "The Dynamics of Issue Competence and Vote for Parties In and Out of Power: An Analysis of Valence in Britain, 1979-1997." European Journal of Political Research 51: 469-503.

Greene, Zachary. 2012. Motivating Parliament: The Policy Consequences of Party Strategy. Ph.D. Dissertation, University of Iowa, USA.

Harmel, Robert and Kenneth Janda. (1994). "An Integrated Theory of Party Goals and Party Change." Journal of Theoretical Politics 6, 3: 259-287.

Harmel, Robert and Alexander Tan. (2003). "Party Actors and Party Change: Does Factional Dominance Matter?” European Journal of Political Research 42, 3: 409-424.

Kim, Dong-Hun and Gerhard Loewenberg. (2005). "The Role of Parliamentary Committees in Coalition Governments: Keeping Tabs on Coalition Partners in the German Bundestag." Comparative Political Studies, 38: 1104-1129.

Klingemann, Hans-Deiter, Andrea Volkens, Judith Bara, Ian Budge, and Michael McDonald. (2006). Mapping Policy Preferences. Estimates for Parties, Electors and Governments in Eastern Europe, the European Union and the OECD 1990-2003. Oxford: Oxford University Press.

Laver, Michael and Kenneth Shepsle. (1996). Making and Breaking Governments: Cabinets and Legislatures in Parliamentary Democracies (Political Economy of Institutions and Decisions). New York, NY: Cambridge University Press.

Lowe, Will, Kenneth Benoit, Slava Mikhaylov, and Michael Laver. (2011). "Scaling Policy Preferences from Coded Political Texts.” Legislative Studies Quarterly 36(1): 123-155. 
Lipsmeyer, Christine S. and Heather Nicole Pierce. (2011). "The Eyes that Bind: Junior Ministers as Oversight Mechanisms in Coalition Governments." Journal of Politics 73(4): 1152-1164.

Martin, Lanny and Georg Vanberg. (2003). "Wasting Time? The Impact of Ideology and Size in Coalition Formation”. British Journal of Political Science, 33(2): 323-332.

Martin, Lanny and Georg Vanberg. (2004). "Policing the Bargain: Coalition Government and Parliamentary Scrutiny” American Journal of Political Science, 48(1): 13-27. 27

Martin, Lanny and George Vanberg. (2005). "Coalition Policy Making and Legislative Review" American Political Science Review, 99(1): 93-106.

Martin, Lanny W., and Georg Vanberg. (2011). Parliaments and Coalitions: The Role of Legislative Institutions in Multiparty Governance. Oxford: Oxford University Press.

Mequid, Bonnie. 2007. Party Competition Between Unequals: Strategies and Electoral Fortunes in Western Europe. New York, NY: Cambridge University Press.

Mershon, Carol. (2001a). "Contending Models of Portfolio Allocation and Office Payoffs to Party Factions: Italy, 1963-1979.” American Journal of Political Science, 45(2): 277-293.

Mershon, Carol. (2001b). "Party Factions and Coalition Government: Portfolio Allocation in Italian Christian Democracy.” Electoral Studies 20:555-580

Petrocik, John. (1996). "Issue Ownership in Presidential Elections, with a 1980 Case Study." American Journal of Political Science 40: 825-850.

Proksch, Sven-Oliver and Jonathan Slapin. (2006). "Institutions and Coalition Formation: The German Election of 2005." West European Politics 29(3): 540-559.

Schattschneider, EE. (1960). The Semisovereign People: A Realist's View of Democracy in America. Holt, Rinehart and Winston.

Schumacher, Gijs, Catherine de Vries and Barbara Vis. 2013. Why do Parties Change Position? Party Organization and Environmental Incentives. Journal of Politics 75 (2): 464-477.

Spoon, Jae-Jae. 2011. Political Survival of Small Parties in Europe. Ann Arbor, MI: University of Michigan Press.

Strøm, Kaare. (1990). “A Behavioral Theory of Competitive Political Parties.” American Journal of Political Science 34 (2): 565-598.

Strøm, Kaare. (2000). "Delegation and Accountability in Parliamentary Democracies." European Journal of Political Research, 37: 261-289. 
Strøm, Kaare, Ian Budge and Michael Laver. (1994). "Constraints on Cabinet Formation in Parliamentary Democracies” American Journal of Political Science, 38(2): 303-335.

Strøm, Kaare and Wolfgang Müller. (2000). Coalition Government in Western Europe. Oxford University Press

Strøm, Kaare, Wolfgang Müller and Torbjörn Bergman. (2008). Cabinets and Coalition Bargaining: The Democratic Life Cycle in Western Europe. Oxford: Oxford University Press.

Tavits, Margit. 2007. "Principle vs. Pragmatism: Policy Shifts and Political Competition." American Journal of Political Science 51(1): 151-65.

Thies, Michael. (2001). “Keeping Tabs on One's Partners: The Logic of Delegation in Coalition Formation.' American Journal of Political Science 45 (3): 580-98.

Timmermans, Arco. (2006). "Standing Apart and Sitting Together: Enforcing Coalition Agreements in Multiparty Systems." European Journal of Political Research, 45: 263283.

Wardt, Marc van de. 2012. "Putting the Damper on Do Parties de-Emphasize Issues in Response to Internal Divisions among Their Supporters?" Party Politics.

Warwick, Paul and James Druckman. (2001). "Portfolio Salience and the Proportionality of Payoffs in Coalition Governments." British Journal of Political Science. 31: 627-649. 


\section{Notes}

${ }^{1}$ It is worth noting that research by Adams et al. (2011) and others calls into question the extent to which voters react to manifesto changes (Adams et al., 2011; Fortunato and Stevenson, 2013). However, Adams et al.'s (2011) interviews with party elites also provide anecdotal evidence in support of a distinction between parts of party manifestos that are "fundamental" and their importance to activists (see interview excerpt, p 372).

${ }^{2}$ Our classification closely relates to Tavits' (2007) distinction between principled and pragmatic issues. She finds that parties are freer to change their positions to act 'pragmatically' on some issues, whereas they are less free to change their positions on principled issues.

${ }^{3}$ We have no similar expectation about policy seeking behavior in policy areas corresponding to voter issues.

${ }^{4}$ Using our approach, the results are broadly similar to Lipsmeyer and Pierce's (2011) analysis and support most of their conclusions using a logit with clustered standard errors. Our primary variables are statistically significant at the .1 level in these replications.

${ }^{5}$ We exclude Denmark from the analysis because they do not use junior ministers.

${ }^{6}$ For a formal description of how we construct these variables see the Appendix.

${ }^{7}$ These categories include the Foreign Affairs, Defense, Interior, Justice, Finance, Economy, Labour, Education, Health, Agriculture, Industry, Environment, and Social Affairs portfolios. For a full description of the logic and CMP codes used for each portfolio category, see Table 2 in Bäck et al. (2011), pages 454-455.

8 By focusing only on the 13 portfolios analyzed by Bäck et al. (2011), our analysis is limited to only 5013 observations. We lose additional observations because of the primary independent variable: percent activist issue. To construct this measure we need measures of each party's platform in the current and previous elections. A number of coalition parties did not earn enough votes in the previous election at time t- 1 to be included in the CMP at that point.

${ }^{9}$ The primary independent variable for issue salience is highly right skewed (greater than 15.8), meaning that a high percentage of the observations are smaller than the mean value of activist issue salience. To account for this skewness, we reran the analysis with multiple alternate transformations of the issue salience variables. Treating each issue type as dummy variables, we find substantively similar results, although the coefficients barely drop below the 90 percent significance level ( $89 \%$ confidence). Taking the multiplicative inverse or exponentiating activist issues leads to coefficients in the correct direction and statistical significance at the 90 percent level. The transformed results are also robust to dropping the most extreme values of issue salience.

${ }^{10}$ The party family dummy variable equals one for the following party portfolio combinations: conservative parties on the Interior, Foreign Affairs and Defense ministries; Christian democratic parties on the Social Affairs, Health and Labour ministries if there is no Socialist party in the coalition or the Agriculture minister if there is no agrarian party; liberal parties on Finance, Economy an Justice ministries; Agrarian parties on the Agriculture ministry; and green parties on the environmental minister.

${ }^{11}$ Like Bäck et al. (2011), we argue that the conditional logit is the most appropriate model to test hypotheses on the allocation of ministers and now junior ministers to portfolios. By essentially including a large number of fixed effects, the model accounts for the major differences between the govern-party observations. As we discuss in greater detail in endnote 14, the results from alternate models with additional controls lead to nearly identical results. ${ }^{12}$ Following Bäck et al. (2011), we checked the coding from Strøm and Müller (2000) for minister and junior minister allocation against online government records from each country. For Germany, we discovered substantial discrepancies. We recoded junior ministers or "Parlamentarische Staatssekretäre" from the German data using Data Handbook published by the German Bundestag: http://www.bundestag.de/dokumente/datenhandbuch/06/06_03/06_03_02.html, accessed 8/12/2013.

We also include data from France in the analysis. Bäck et al. (2011) exclude France because of a large number of coding errors in the original data. We recoded this data by checking the party minister's name from each ministry website and then check the party affiliation from the online archives of the Assemblée Nationale and Senat. This leads us to include 12 portfolios; the Ministre des Affaires étrangères (Foreign Affairs), Ministre de l'intérieur (Interior), Ministre de la justice (Justice), Ministre des finances (Finance), Ministre de la defense (Defense), Ministre du travail (Labour), Ministre de L'éducation nationale (Education), Ministre de la santé (Health), Ministre de l'agriculture (Agriculture), Ministre de l'industrie (Industry), Ministre de l'environnement (Environment), and the Ministre des affaires sociales (Social Affairs).

${ }^{13}$ Unlike Bäck et al. (2011) we condition our analysis on each party in government. If we treat the governmentportfolio as the grouping variable, the conditional logit drops all portfolios that do not have a junior minister 
appointed to it leaving us with less than 720 observations in the full model. While the coefficient is significant and in the expected direction for activist issues in the simple model, its interaction with ideological disagreement is not statistically different from zero in the final model. A Wald test of the joint significance indicates that the effect of activist issues, the interaction and disagreement is jointly positive and significant with $95 \%$ confidence in the government-portfolio models. The results for models using only the government as the grouping variable are largely similar to those reported, although the coefficient for the interaction is not statistically significant. A Wald test of joint significance indicates that the coefficients for activist issues and the interaction are jointly statistically significant at the .1 level. We use robust standard errors in all models.

${ }^{14}$ The conditional logit model limits the analysis to variables that vary within the government-party observation. This we are constrains from using some additional control variables that do not vary across the party level in a government such as the percentage seats or median party status. Alternative models using random effects (which allow for variables that do not vary for each party in a government), that include variables such as the party's percentage seat shares lead to nearly identical results for our primary independent variables. As Gamson's law might predict, parties contributing more seats to the cabinet have an increased likelihood of controlling a junior minister (Falcó-Gimeno and Indridason, 2013)

${ }^{15}$ The predicted effects are computed holding each of the continuous variables at their mean and the dichotomous variables at zero. In particular, these conditions are for a portfolio ranked 1.16, disagreement of .84 between the minister and the coalition mean, and that is not interested in the portfolio based on its party family. The high level of salience in the figure is most similar to the situation faced by the Portuguese Socialist Party (PSP) in 1983 in relation to the Agriculture Minister. The Social Democratic Party controlling the Minister was ideologically distant (.38) and the PSP also dedicated 21.31 percent of its platform to related issues. Similar to expectations from the theory, the PSP placed a junior minister on this portfolio in 1983.

${ }^{16} \mathrm{~A}$ Wald test of the joint significance of the coefficients indicates that the interaction is positive and significant with greater than $95 \%$ confidence.

${ }^{17}$ Similar to Lowe et al. (2011) we combine each of the 14 confrontational codes into 7 codes using the following categories: "Foreign Special Relationships: positive", "Foreign Special Relationships: negative", "Military: positive", "Military: negative", "Internationalism: positive", "Internationalism: negative", "European Community: positive", "European Community: negative", "Constitutionalism: positive", "Constitutionalism: negative", "Decentralisation", "Centralisation", "Protectionism: Positive", "Protectionism: negative", "Welfare State Expansion", "Welfare State Limitation", "Education Expansion", "Education Limitation", "National Way of Life: positive", "National Way of Life: negative", "Traditional Morality: positive", "Traditional Morality: negative", "Multiculturalism: positive", "Multiculturalism: negative", "Labour Groups: positive" and "Labour Groups: negative" 